INTERNATIONAL JOURNAL OF MULTidisciplinARY RESEARCH AND ANALYSis

ISSN(print): 2643-9840, ISSN(online): 2643-9875

Volume 05 Issue 02 February 2022

DOI: 10.47191/ijmra/v5-i2-42, Impact Factor: 6.072

Page No. $542-548$

\title{
Students' Common Errors in Solving Routine \& Non-Routine Problems: A Mixed Method Analysis
}

\author{
Michael Angelo A. Legarde \\ Palawan State University, Puerto Princesa City, Palawan
}

ABSTRACT: This research was conducted to identify errors committed by students in solving word problems, determine their possible causes and propose corrective measures for classroom teaching. The analysis was centered on the five errors adopted from Newman's Error Analysis Guide namely: reading, comprehension, transformation, process, and encoding.

The study used a mixed-method research design. In collecting errors, the students were given a series of test questions. The results of the tests were compared and the specific error patterns along with the probable sources were descriptively investigated. Two weeks after the test, students were interviewed to identify their misconceptions and their reasoning. In the interview process, students were asked to explain their thinking while they were doing the same problems again. Some prompting questions were asked to facilitate this process and to clarify more about students' claims. The data gathered were treated statistically using frequency count, mean percentage, and test concerning two means.

Findings reveal that some of the common errors were seen to be persistent and the sources from which they derive were not consistent. Thus, the students' errors occurred in varied ways in problem-solving situations. Analysis of error patterns led to the conclusion that the students have difficulty on algebraic symbolism and analysis of the problem. Their inability to deduce the correct meaning of mathematical statements further create a chain of errors on succeeding steps required of a mathematical word problem.

The conclusions drawn from this investigation strongly justify the needs to recognize and to develop critical and analytical thinking of the students. That is, students must be expose in solving non-routine problems in order to provide them an opportunity to develop higher-order thinking in the process of understanding, analysis, exploration, and application of mathematical concepts.

KEYWORDS- Routine and Non-Routine Problems, Error Analysis, Problem Solving Heuristics, Misconceptions, Mixed-Methods

\section{INTRODUCTION}

Twenty-first century mathematics education is about facing novel real-world problems, nurturing creative thinking skills, and cultivating productive ways of learning. Many educators have embarked on searching for new teaching methods, as well as seeking innovations on teaching and learning to prepare the youth for the demands of this new era. Nowadays, there are many ways to learn and understand mathematics and connect it to the experiences that the students have outside of school (Cusco, 1995). Hence, educators have been shifting their views in teaching mathematics towards a more learner-centered focus where the students take active role in the discovery of the ideas.

Mathematics in the real sense is a science of space and quantity that provides opportunity for the intellectual gymnastic of the man's inherent powers. It is an exact science which involves high cognitive abilities. It is an important subject; its usefulness cuts across all spheres of life such as commerce, science, computer processing, engineering and music. However, it is quite ironic that something so vital is disliked and feared by so many students. Some students even consider it as a roadblock rather than a gateway to choosing a career. Because of this, mathematics educators are challenged to overcome hindrances to mathematics learning in school. Therefore, it becomes imperative for the teacher to motivate the students to love mathematics for it will prepare them for more challenging tasks in the future.

Problem solving has long been recognized as one of the hallmarks of mathematics and is now being encouraged to be the main activity in all mathematics classes. Students should be encouraged to work on problems that may take hours, days, and even weeks to solve to develop effective problem-solving activity (Mikusa, 1998). It has been observed that students lack the 


\section{Students' Common Errors in Solving Routine \& Non-Routine Problems: A Mixed Method Analysis}

necessary skills to engage in real-life problem solving outside the school setting. This is because students are only trained to work on routine problems that have well-defined goals where all the needed information are given to be able to solve a problem.

Word problems can be classified as routine or non-routine. According to Polya (1962), solving a routine problem does not contribute to the mental development of the student. He believed that non-routine problems should be employed to provide students an opportunity to develop higher-order thinking in the process of understanding, analysis, exploration, and application of mathematical concepts. However, students generally fear the idea of solving non-routine problems because these problems are usually non-standard and involve unexpected or unfamiliar solutions. Students also become apprehensive, anxious, and uncomfortable since they are not able to recall and apply learned procedures in a straightforward manner.

It is further noted that common errors in mathematics are held not only by low achieving students but also by high achieving students, thereby hindering the learning process (Wetzel, 2008). It is also observed that students, particularly those who belong to the lower and upper quartiles of the class, commit minor and major errors in computation. These errors arise from their lack of mastery and misconceptions in solving problems, thereby hindering their mathematics proficiency. Thus, teachers need to look for these patterns and correct such by making students realize that these are indeed errors in need of correction. Thinking along this line, the researcher's question about the students' common errors in solving word problems becomes the impetus for this research study.

\section{RESEARCH PROBLEMS}

The main purpose of this study is to identify the error patterns and misconceptions of the students in solving word problems. Specifically, this study sought to provide answers to the following queries:

1. What are the common errors committed by students in solving routine and non-routine problems?

2. At what stage do the high and low achieving students commit the least and greatest error in solving routine and nonroutine problems?

3. Are there significant differences between the high and low achieving groups in solving routine and non-routine problems with respect to:

A. Error patterns

B. Percentage of errors committed at each stage?

\section{CONCEPTUAL FRAMEWORK}

Most of the times, students do not understand why they are having math problems (Wijaya, 2006). Students may struggle with one or more areas in math and thereby, make errors as they attempt to solve word problems (Russel, 2006). As cited by Li (2006), Booth (1988) pointed out that one way of trying to find out what makes mathematics difficult is to identify the kinds of errors students commonly make in this subject and investigate the reasons for these errors. This was echoed by White (2000) who recommended conducting error analysis to determine why students make the mistakes and often repeat the same mistake will minimize habitual errors.

One guide for analyzing students' error in solving word problem is the Newman's Error Analysis (NEA). White (2005) notes that Newman's Error Analysis (NEA) provides the framework in identifying the reasons that underlie the difficulties learners face in solving math problem. He explained that NEA allows the analysis of potential problems and then identifies ways to resolve these problems. The conceptual model (refer to figure 1), highlights the concept that when learners confronted word problems, they have to surmount a number of hurdles including reading, comprehension, transformation, process, and encoding.

Reading errors are committed when someone could not read a key word or symbol in the written problem to the extent that this prevented him from writing anything on his solution. Comprehension errors are committed when someone had been able to read all the words in the problem, but had not grasped the overall meaning of the words. Transformation errors are committed when someone had understood what the problems wanted him to find out but was unable to identify the operation, or sequence of operations or the working equation needed to solve the problem. Processing errors are committed when someone identified an appropriate operation, or sequence of operations or the working equation but did not know the procedures necessary to carry out these operations accurately. The encoding errors are committed when someone correctly worked out the solution to a problem, but could not express this solution in an acceptable written form. 
Students' Common Errors in Solving Routine \& Non-Routine Problems: A Mixed Method Analysis

\begin{tabular}{|c|c|c|}
\hline \multirow{6}{*}{$\begin{array}{l}\text { Word Problems } \\
\circ \text { Routine } \\
\circ \text { Non-Routine }\end{array}$} & $\begin{array}{l}\text { Stages in } \\
\text { Problem Solving }\end{array}$ & Error Categories \\
\hline & Reading & Reading Errors \\
\hline & Comprehension & Comprehension Errors \\
\hline & Transformation & Transformation Errors \\
\hline & Processing & Processing Errors \\
\hline & Encoding & Encoding Errors \\
\hline
\end{tabular}

\section{METHODOLOGY}

The nature of the research problems raised in this investigation lend themselves to a mixed method design which is characterized by the collection and analysis of quantitative data followed by the collection and analysis of qualitative data (Creswell, 2003). Typically, the purpose of a mixed method design is to use qualitative results to assist in explaining and interpreting the findings of a primarily quantitative design. The initial quantitative phase of the study may be used to characterize individuals along certain traits of interest related to the research questions. These quantitative results can then be used to guide the purposeful sampling of participants for a primarily qualitative study. The findings of the quantitative study determine the type of data to be collected in the qualitative phase (Gay, Mills and Airasian, 2006).

Consistent with mixed-method design adopted in this study, a combination of quantitative and qualitative measures were used to collect data to answer the research questions raised in the preceding chapter. In the quantitative part of this study, the researcher used a test instrument to identify and classify student errors. A total of 10 -item problems solving test were used in the study as part of the subject course requirements in Math 4: Solid Mensuration. Interviews were then be conducted to unravel students' reasoning and misconceptions that resulted in such errors in the qualitative part of the study. In this study, an interview technique guided by Newman's Error Analysis was used to further clarify the errors made by the students and the reasons for such errors. A key assumption in this interview technique is that the types of errors students make will be consistent from one problem to another.

The procedure can be described as follows: Metacognitive questions are shown in italics.

\begin{tabular}{|c|c|c|}
\hline Classification & Typical questions & Error classification \\
\hline Reading & $\begin{array}{l}\text { Please read the question to me. } \\
\text { If you don't know a word, leave it out. }\end{array}$ & $\begin{array}{l}\text { The student could not read a key word or symbol in the } \\
\text { written problem to the extent that this prevented him/her } \\
\text { from proceeding further along an appropriate problem- } \\
\text { solving path. }\end{array}$ \\
\hline Comprehension & $\begin{array}{l}\text { Tell me what the question is asking you to } \\
\text { do. } \\
\text { What do you mean when you say...? }\end{array}$ & $\begin{array}{l}\text { The student has been able to read all the words in the } \\
\text { question, but has not grasped the overall meaning of the } \\
\text { words and, therefore, was unable to proceed further along } \\
\text { an appropriate problem-solving path. }\end{array}$ \\
\hline Transformation & $\begin{array}{l}\text { Tell me the method you can use to find an } \\
\text { answer to the question. } \\
\text { How will you start to find an answer to } \\
\text { this question? }\end{array}$ & $\begin{array}{l}\text { The student had understood what the questions wanted } \\
\text { him/her to find out but was unable to identify the } \\
\text { operation, or sequence of operations need to solve the } \\
\text { problem. }\end{array}$ \\
\hline Process skills & $\begin{array}{l}\text { Show me how you worked out the answer } \\
\text { to the question. } \\
\text { Explain to me what you are doing as you } \\
\text { do it. } \\
\text { Do you know you are right? Why? }\end{array}$ & $\begin{array}{l}\text { The student identified an appropriate operation, or } \\
\text { sequence of operations, but did not know the procedures } \\
\text { necessary to carry out these operations accurately. }\end{array}$ \\
\hline Encoding & $\begin{array}{l}\text { Now write down your answer to the } \\
\text { question. } \\
\text { How confident do you feel about the } \\
\text { answer? }\end{array}$ & $\begin{array}{l}\text { The student correctly worked out the solution to the } \\
\text { problem, but could not express this solution in an } \\
\text { acceptable written form. }\end{array}$ \\
\hline
\end{tabular}




\section{Students' Common Errors in Solving Routine \& Non-Routine Problems: A Mixed Method Analysis}

\section{RESULTS}

\section{A. Students' Errors in Solving Routine Problems}

Generally, in solving routine problems, about 3 to 6 high achieving students made errors along encoding. These students were able to understand the problem and perform accurate calculation but failed to indicate the unit and simplify the final answer. Moreover, 0 to 3 students go beyond transformation level but failed to perform accurate calculation correctly. These errors were made due to some misconceptions and misunderstandings in some mathematical concepts. This was corroborated with the claim echoed by David (2007) as cited by Colendra (2009) that errors committed by the students is the product of misconceptions and weak computational fluency. In addition, 0 to 2 students committed transformation errors. These students could interpret the problem but could not fully translate the sentence "the length is three times its width" into mathematical sentences. This result agree with the study of Ragma (2014) revealing that most of the transformation errors made by students were due to insufficient understanding of mathematical expressions and poor skills along mathematical translation. It is also good to note that no high achieving student committed errors along reading and comprehension stages.

On the other hand, about 1 to 10 low achieving students made mistakes along encoding. Though these students fully understand the problem and perform perfect calculation, they were failed to indicate the unit in their final answer. Moreover, 1 to 9 students committed errors along the process stage. These students went beyond transformation level, but failed in working the correct solution. About 1 to 4 students made errors along transformation. Most of them made errors in translating mathematical sentences into mathematical expressions. This finding relates to the study of Colendra (2009) revealing that low achieving students failed to translate word problems into corresponding mathematical sentences.

\section{B. Students' Errors in Solving Non-Routine Problems}

In solving non-routine problems, about 2 to 8 high achieving students committed mistakes along processing stage. These students were able to understand what the questions wanted them to find out and identify series of operations or formulate the working equations needed to solve the problem however, failed to correctly write the solution. These results agree with the study of Ragma (2014) revealing that most of the students committed processing errors along word problems involving algebra concepts. He stated that the students lacked critical analysis as to when and how to end the mathematical process correctly. About 0 to 3 students made mistakes along comprehension. These students failed to understand the problem and most students left the problem unanswered. This means that the students did not know what to do and what the problem is talking about. These corroborates with the findings of Hall (2007) emphasized that most students who find difficulty in understanding the problem often abandon solving such problems.

Contrariwise, about 4 to 9 low achieving students were able to go beyond reading level but failed to completely and correctly understand the problem. Most comprehension errors occur when students do not understand mathematical sentences and terms used and some students often misunderstood what the questions wants. This weakness is probably due to the lack of balance between understanding of mathematical concepts and arithmetic skills. The findings run parallel to Zacaria (2010) divulging that students always make errors in understanding the terms used in the problem since the mathematical terminology is being ignored. This confirms that lack of proficiency in English is indeed a hindrance in mathematics learning. Furthermore, 1 to 4 students made processing errors. These students failed to understand and describe what is being required in the problem. Most students did not manage to perform appropriate method, thus results in failure to solve the problems. The students also failed to do computation correctly and perform operations involving algebraic expressions.

\section{Differences in the Error Patterns by High and Low-Achieving Students}

To investigate differences of patterns of errors among groups compared, test concerning two means was carried out. The two groups involved in this investigation were compared in terms of the errors they committed at each stage of problem solving process. Doing this may clarify if error patterns of the results may be connected to the students' achievement. It is of great interest in this study to better understand the convergence and divergence of high and low-achieving students' errors in solving word problems.

It can be seen in Table 1 that in solving word problems, the errors usually committed by the students in the high achieving group and low achieving group had significant differences. At 0.05 level of significance, the p-values confirm that the differences among students' achievement and pattern of errors they made at each stage are statistically significant. These results support the hypothesis that the pattern of errors committed by high achievers and students from the lower group significantly differ. Hence, there is variability of errors were committed by students when grouped according to their achievement as they solve word problems. 
Students' Common Errors in Solving Routine \& Non-Routine Problems: A Mixed Method Analysis

Table 1. Differences in the Error Patterns of the Students in Solving Word Problems (by group: high and low group)

\begin{tabular}{|c|c|c|c|c|c|c|}
\hline \multirow{2}{*}{$\begin{array}{l}\text { Error Patterns } \\
\text { (by group-high and low) }\end{array}$} & \multicolumn{3}{|c|}{ Routine Problem } & \multicolumn{3}{|c|}{ Non-Routine Problem } \\
\hline & Mean & t-value & $p$-value & Mean & t-value & p-value \\
\hline \multirow[t]{2}{*}{ Reading Error } & - & \multirow[t]{2}{*}{-} & \multirow[t]{2}{*}{-} & - & \multirow[t]{2}{*}{-} & \multirow[t]{2}{*}{-} \\
\hline & - & & & - & & \\
\hline \multirow[t]{2}{*}{ Comprehension Error } & - & \multirow[t]{2}{*}{-} & \multirow[t]{2}{*}{-} & $3^{1}$ & \multirow[t]{2}{*}{5.6308} & \multirow[t]{2}{*}{$0.0000^{* *}$} \\
\hline & - & & & $0.67^{h}$ & & \\
\hline \multirow[t]{2}{*}{ Transformation Error } & $1^{\prime}$ & \multirow[t]{2}{*}{2.6018} & \multirow[t]{2}{*}{$0.0163^{* *}$} & $1.08^{\prime}$ & \multirow[t]{2}{*}{3.0890} & \multirow[t]{2}{*}{$0.0054^{* *}$} \\
\hline & $0.333^{h}$ & & & $0.08^{h}$ & & \\
\hline \multirow[t]{2}{*}{ Processing Error } & $1.167^{\prime}$ & \multirow[t]{2}{*}{2.612} & \multirow[t]{2}{*}{$0.0159^{* *}$} & $2.4167^{\prime}$ & \multirow[t]{2}{*}{2.4881} & \multirow[t]{2}{*}{$0.0209^{* *}$} \\
\hline & $0.5833^{h}$ & & & $1.5^{\mathrm{h}}$ & & \\
\hline \multirow[t]{2}{*}{ Encoding Error } & $1.9167^{\prime}$ & \multirow[t]{2}{*}{2.2930} & \multirow[t]{2}{*}{$0.0077^{* *}$} & $1.4167^{\prime}$ & \multirow[t]{2}{*}{4.0206} & \multirow[t]{2}{*}{$0.0006^{* *}$} \\
\hline & $1^{\mathrm{h}}$ & & & $0.333^{h}$ & & \\
\hline
\end{tabular}

${ }^{* *}$ Significant at 0.05 level of significance

Note: Superscript indicates the mean number of errors of the two groups (e.g., h-high group and I-low group)

\section{Differences in the Number of Errors Committed by High and Low-Achieving Students}

It may also be recalled that students' errors in solving word problems were analyzed using Newman's Error Analysis Guide. This guide involves series of stages where students usually committed errors as they solve mathematical problems. Number of errors can be drawn at each stages in solving word problems from the combined solution of the two groups of participants.

Apparently, it is the interest of this study to better understand differences of the number of errors committed at each stage of the participants who were dichotomized as high and low achieving group. That is, they were classified as members of the high-achieving group as their grades fall in the third quartile (upper 25\%) and to the low group as their grades are in the first quartile (lowest 25\%). Doing this may elucidate if number of errors at each stages may be connected to students' achievement. To investigate differences among groups compared, test concerning two means was utilized.

As explicitly suggested by the data captured by Table 2 , at 0.05 level of significance, the solution submitted by the students in solving word problems reveals that there is a significant difference between the number of errors made at each stage by high achieving students and students working with the lower group. That is, number of errors committed by students from the two groups are significantly varied. The indicated $p$-values tested at 0.05 level of significance, are all statistically significant.

Table 2: Differences in the Number of Errors Committed at Each Stage in Solving Word Problems (by group: high and low achieving)

\begin{tabular}{|c|c|c|c|c|c|c|}
\hline \multirow[t]{2}{*}{ Stages } & \multicolumn{3}{|c|}{ Routine Problem } & \multicolumn{3}{|c|}{ Non-Routine Problem } \\
\hline & Mean & t-value & $p$-value & Mean & t-value & $p$-value \\
\hline \multirow[t]{2}{*}{ Reading } & - & \multirow[t]{2}{*}{-} & \multirow[t]{2}{*}{-} & & \multirow[t]{2}{*}{-} & \multirow[t]{2}{*}{-} \\
\hline & - & & & & & \\
\hline \multirow[t]{2}{*}{ Comprehension } & - & \multirow[t]{2}{*}{-} & \multirow[t]{2}{*}{-} & $0.7^{\mathrm{h}}$ & \multirow[t]{2}{*}{9.2159} & \multirow[t]{2}{*}{$0.000^{* *}$} \\
\hline & - & & & $6.2^{1}$ & & \\
\hline \multirow[t]{2}{*}{ Transformation } & $0.6^{\mathrm{h}}$ & \multirow[t]{2}{*}{4.5537} & \multirow[t]{2}{*}{$0.0002^{* *}$} & $0.8^{\mathrm{h}}$ & \multirow[t]{2}{*}{2.6783} & \multirow[t]{2}{*}{$0.0137^{* *}$} \\
\hline & $2.8^{1}$ & & & $1.9^{\prime}$ & & \\
\hline \multirow[t]{2}{*}{ Processing } & $1.1^{\mathrm{h}}$ & \multirow[t]{2}{*}{4.5388} & \multirow[t]{2}{*}{$0.002^{* *}$} & $1.8^{\mathrm{h}}$ & \multirow[t]{2}{*}{3.4123} & \multirow[t]{2}{*}{$0.0025^{* *}$} \\
\hline & $3.0^{1}$ & & & $3.2^{1}$ & & \\
\hline \multirow[t]{2}{*}{ Encoding } & $3.0^{\mathrm{h}}$ & \multirow[t]{2}{*}{3.1920} & \multirow[t]{2}{*}{$0.0042^{* *}$} & $1.3^{\mathrm{h}}$ & \multirow[t]{2}{*}{5.0187} & \multirow[t]{2}{*}{$0.0004^{* *}$} \\
\hline & $4.5^{1}$ & & & $3.5^{1}$ & & \\
\hline
\end{tabular}

** Significant at 0.05 level of significance

Note: Superscript indicates the mean number of errors of the two groups (e.g., h-high group and I-low group)

\section{CONCLUSIONS}

One of the goals of this investigation was to identify and compare errors committed by students in solving word problems. This investigation is classified as mixed-methods design which tried to capture the strengths of both quantitative and qualitative research. Consistent with this end, students were bifurcated into high and low achieving group. As discussed in the preceding part 


\section{Students' Common Errors in Solving Routine \& Non-Routine Problems: A Mixed Method Analysis}

of this study, participants belonging to high group were those whose general weighted average belonged to the first quadrant, whereas members of low group were those whose grades belong to the fourth quadrant.

The data were obtained by means of two sets of word problems which were administered in one time point. Error analysis was done by adopting Newman's Error Analysis Guide. Statistical calculations such as frequencies, percentages, means, standard deviations, and test concerning two means were used to analyze the data gathered.

The analyses suggest the errors usually made by the students in solving routine and non-routine problems varied, hence it can be deduced that students have difficulty in dealing with non-routine problems which involve unexpected and unfamiliar solutions and requires higher-order thinking in the process of understanding, analysis, exploration, and application of mathematical concepts. It is also good to note that students working with the higher group committed lesser errors than their counterparts in solving mathematical problems. Therefore, mathematics educators may need to be reminded once again that they can design learning experiences in mathematics classroom which enable students to manifest deeper understanding of mathematical concepts and develop their numerical skills. This is to realize the goal of improving students' mathematics achievement and to reduce mathematical errors. Moreover, Mathematics teachers are likewise recommended to expose their students in solving nonroutine problems since the analyses revealed that students generally fear the idea and feel uncomfortable in working this type of problem. That is, mathematics educators must recognize the need to develop critical and analytical thinking of the students through problem solving.

\section{REFERENCES}

1) Allen, D. (2007). - Misconception analysis in algebra." Dissertation. Texas A \& M University. Retrieved August 12, 2015, from http://www.math.tamu.edu/ snite/MisMath.pdf

2) Artizuela, M. A. (2008). Effects of DAMATH Remedial Instruction on the Performance and Attitude of Grade three-Low Achievers in Mathematics. Palawan State University.

3) Ashlock, R. B. (2002). Error patterns in computation: Using error patterns to improve instruction. Upper Saddle River, NJ: Prentice Hall.

4) Bucsit, M. E. (2009). - Determinants of math I (college algebra) performance of freshmen computer science of private schools in San Fernando City." Master's Thesis. Don Mariano Marcos Memorial State University-Mid-La Union Campus, San Fernando City, La Union.

5) Cansiz S. A. (2011). Identifying the Secondary School Students' Misconception about Functions. Retrieved August 03, 2015, from Pearson; Merrill Prentice Hall,

6) Clements, M.A. (1980) Analyzing children's errors on written mathematical task. Educational Studies in Mathematics.

7) Creswell, J. W. (2005). Research Design: Qualitative, quantitative and mixed methods approaches. SAGE Publications.

8) Clements, M. A. (1982). Careless errors made by sixth-grade children on written mathematical tasks. Journal for Research in Mathematics Education.

9) Colendra, R. P. (2009). Reducing Second Year Low-Achieving Students Errors in Algebraic Rational Expressions through Computation Journals. Palawan State University.

10) Doorman, M. A. (2012). Difficulties in Solving Context-Based PISA Mathematics Tasks: An Analysis of Students Errors. Institute for Science and Mathematics Education, Utrecht University, the Netherlands.

11) Egodawatte, G. W. (2009). Is algebra really difficult for all students? Canada. Retrieved March 20, 2015 from http://dppd.ubbcluj.ro/adn/article_2_4_10.pdf

12) Ellerton, N. F., \& Clements, M. A. (1996). Newman error analysis. A comparative study involving Year 7 students in Malaysia and Australia. In P. C. Clarkson (Ed.), Technology and mathematics education (pp. 186-193). Melbourne: Mathematics education Research Group of Australia.

13) Garcellano, A. C. (2014). I Enjoy my Math Class! : Exploring the Social-Cognitive Antecedent of Academic Emotions: A Mixed-Method Analysis. Palawan State University.

14) Hall, R. D. (2007). An Analysis of Students' Errors in Problem Solving. Journal for Research in Mathematics Education.

15) Lapinid, M. C. (2014). Students' Difficulties in Translating Worded Problems into Mathematical Symbols. De La Salle University, Manila Philippines.

16) Li, X. O. (2006). Cognitive Analysis of Students' Errors and Misconceptions. Unpublished Dissertation. University of Texas.

17) Liu, Kuiyan, et al (2007). A study of college readiness for college algebra. Retrieved January 12,2015 from http://uwf.edu/cutla/publications/Study_of_College_Readiness_for_College_Algebra.pdf

18) Limjap, A. A., \& Candelaria, M. A. (2002). Problem Solving Heuristics of College Students: A Case Analysis. The Asia-Pacific Education Researcher. 


\section{Students' Common Errors in Solving Routine \& Non-Routine Problems: A Mixed Method Analysis}

19) Mangulabnan, P.A. (2013). Assessing Translation Misconceptions Inside the Classroom: A Presentation of an Instruments and its Results. De La Salle University, Manila Philippines.

20) Mikusa, Michael G. (1998). Problem solving in More Than Solving Problems. Mathematical Problem Solving in Middle School. Volume 4, No.1, September 1998.

21) Montague, M., \& Bos, C.S. (2000). The effect of cognitive strategy training on verbal math problem solving performance of college students.

22) Mukhuntan, T. C. (2010). A Study on Students' Errors on Word Problems. Early Childhood and Primary education. Open University of Sri Lanka.

23) Nanayakara, G. L. (2003). Assessment of pupil Achievement in Primary Mathematics with Special Reference to Analysis of Pupil Errors. Unpublished Doctoral Dissertation, Sussex University.

24) National Council of Teachers of Mathematics (2000). Problem solving standards for grades 9-12. In Principles and standards for school mathematics. [On-line] Available: http://standards.nctm.org/document/chapter7/prob.htm

25) Newman, A. M. (1977). An analysis of sixth grade pupils' errors on written mathematical tasks. Research in mathematics education in Australia. Melbourne: Swinburne Press.

26) Newman, A. M. (1977). Strategies for diagnosis and remediation.|| Victorian Institute for Educational Research Bulletin. Sydney: Harcourt, Brace Jovanovich. Retrieved July 5, 2015 from http://www.compasstech. com.au/ ARNOLD /PAGES/newman.htm

27) Peng, A. (2007). Teacher knowledge of students' mathematical misconceptions." Thesis. M.S. in. Sweden. Retrieved July 23, 2015 from http:// math. coe. uga. edu/tme/Issues/v21n2/4-21.2_Cheng\%20\&\%20Yee.pdf

28) Polya, G. (1973). How to solve it: A new aspect of mathematical method. Princeton, N. J.: Princeton University Press.

29) Raduan, I. H. (2009). Error Analysis and the Corresponding Cognitive Activities Committed by Students in Solving Mathematical Word problems. Mathematics Department. Institute of Teacher Training.

30) Ragma, F. G. (2014). Error Analysis in College Algebra in Higher Education Institutions in La Union. Unpublished Dissertation. Saint Louis University.

31) San Gabriel, Virginia J. (2011). “Exploring the Errors Committed by Students in Solving Word Problems Using Newman's Error Analysis". College of Science, Philippine Normal University, Taft Avenue, Manila.

32) Sia, A. R. (2012). Students' Performance, Error Patterns and Attitudes towards Solving Word Problems in Algebra. Isabela State University. Philippines.

33) Tan, J.A. (2009). Students' Problem Solving Performance as Moderated by their Academic Achievement. Unpublished Dissertation.

34) Trance, N. J. (2013). Process Inquiry: Analysis of Problem Solving-Skills in Mathematics of Engineering Students. Unpublished Dissertation. Western Visayas College of Science and Technology.

35) White, A. L. (2009). Diagnostic and Pedagogical Issues with Mathematical Word Problems. Unpublished Dissertation. University of Southern Sydney.

36) White, A. L., \& M. A. Clements (2005). Energizing upper-primary mathematics classrooms in Brunei Darussalam: The Active Mathematics in Classrooms (AMIC) Project. In H. S. Dhindsa, I. J. Kyeleve, O. Chukwu, \& J. S. H. Q. Perera (Eds.). Future directions in science, mathematics and technical education (pp. 151-160). Brunei Darussalam: University Brunei Darussalam.

37) Woodward, J. (2004). Mathematics education in the United States: Past to present. Journal of Learning Disabilities, 37, 1631. Retrieved July 23, 2015

38) Yeo, K. J. (2011). Secondary Students' Difficulties in Solving Word Problems. National Institute of Education, Nanyang Technological University.

39) Yeo, K. J. (2011). An Exploratory Study on primary Two Pupils' Approach to Solve Word problems. National Institute of Education, Nanyang Technological University.

40) Yusof, J. M. (2003). Mathematical Errors: A case of Bruneian Five-Primary Pupils. Curtin University of Technology.

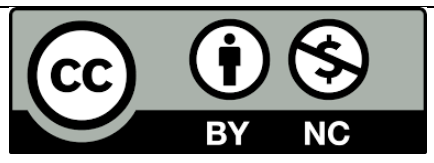

There is an Open Access article, distributed under the term of the Creative Commons Attribution - Non Commercial 4.0 International (CC BY-NC 4.0)

(https://creativecommons.org/licenses/by-nc/4.0/), which permits remixing, adapting and building upon the work for non-commercial use, provided the original work is properly cited. 